\title{
Heterosis and Correlations Studies for Flowering Characters, Yield and Yield Components in Squash (Cucurbita Pepo L.) \\ Badr, L.A.A. ${ }^{1}$; M.M.M. El-Nagar ${ }^{1}$; Sharaf T.E.S. ${ }^{2}$ \\ ${ }^{1}$ Horticulture Dept., Faculty of Agriculture, Benha University, Benha, Egypt. \\ ${ }^{2}$ Misr Hytech seed Int. Co. Egypt. \\ Corresponding author: eid talaat@yahoo.com
}

\begin{abstract}
The main goal of this study is to investigate inheritance of some economic characters of squash genotypes and its hybrids and reciprocals. This experiment was carried out during 2017 and 2018 seasons. Ten advanced inbred lines of summer squash (Cucurbita pepo L.) named MHSQ-1= P1, MHSQ-2= P2, MHSQ-3= P3, MHSQ4= P4, MHSQ-5= P5, MHSQ-6= P6, MHSQ-7= P7, MHSQ-8= P8, MHSQ-9= P9 and MHSQ-10= P10 were planted in Misr Hytech seed int. Co. research farm. The advanced 10 inbred lines were used in complete diallel mating design to study genetic parameters of some economic characters viz., number of days to first female flower (D.F.F.F.), sex ratio, fruit weight (F.W. g), total soluble solids percentage (T.S.S \%), number of fruits per plant (N.F.P.) and total yield per plant (T.Y.P. g) of resulted ninety straight and reciprocal F1 hybrids relative to mid and better parents and two commercial check cultivars "Aziad and New Eskandarani". Results of mean squares for (D.F.F.F.) traits exhibited that significant or high significant for all types of variations. Moreover, sex ratio was high significant for all types of variations. Mean squares for fruit weight (F.W.) was significant or high significant for all types of variations except reciprocal effect. T.S.S recorded insignificant values of mean squares. Mean squares for (N.F.P.) and (T.Y.P.) characters were found high significant. Heterosis for (D.F.F.F.) and sex ratio traits showed different levels of significance with positive and negative values except some hybrids. Heterosis (F.W ) and (T.S.S.) exhibited some hybrids with significant or high significant positive or negative values. Heterosis for (N.F.P.) and (T.Y.P.) showed several hybrids having different heterotic effects. Phenotypic Correlation coefficient analysis showed different degrees of correlations between all studied traits.
\end{abstract}

Keywords: heterosis , correlations, squash, flowering, yield.

\section{Introduction}

The Cucurbitaceae is a remarkable plant family, deserving of attention because of its economic, aesthetic, cultural, medicinal, and botanical significance.

Summer squash having somatic chromosome number $2 n=40$ of small, dot like chromosomes. The term" squash" was evidently derived from a north eastern American Indian word indicating a fruit, apparently cucurbita pepo L., eaten Raw (uncooked) as an immature fruit or consumed for the mature seed. (Whitaker and Robinson, 1986).

Summer squash are the edible young (several days after anthesis) fruit of cucurbita pepo, a highly divers species. Easy to grow, short-season crop. There are six extant horticultural groups of summer squash: cocozelle, croocknek, straightneck, scallop, vegetable marrow and zucchini. Summer squash is adapted to temperate and subtropical climates and grown in many regions. The acceptable fruit size range is belongs to the market demand and it differs among markets. A conservative estimate of the worldwide value of this crop is several billion dollars annually, ranking summer squash relatively high among vegetable crops in economic value. Production and per capita consumption appeared to be risen during last decade. Among the largest producers of summer squash are Turkey, Italy, Egypt, Spain, U.S.A., and Mexico. (Paris, 1996).

China, India, Iran, Turkey, Egypt, and the U.S. are among the world's largest producers of cucurbits.
China remains the world's leading producer of the major cucurbits, exporting fresh fruits, watermelon, and squash seeds (Maynard, 2001).

Eskandarani type is the most adapted zucchini summer squash cultivar planted in Egypt compared to accessed cultivars and hybrids (Waly and Nassar, 1978 ; Damarany et al., 1995 ; Hassan, 1988).

The estimated area of summer squash in Egypt was 56.696 feddan with total yield 462.654 tons and average yield 8.16 tons per feddan (Department of Agriculture Economics and Statistics, Ministry of Agriculture and land reclamation A.R.E. 2017.

The prices of imported squash hybrids are very high. So, the recommendation of producing local hybrid seeds is an urgent need to reduce the cost for the farmers and saving hard currency.

The costs of hybrid seed production in summer squash are very low when compared with that of the hybrid seed production from other vegetable crops (Metwally, 1985).

The main goal of this study is to select the best combinations of squash genotypes which reflect desired characters for consumer depending on estimation of genetic parameters for all studied traits.

\section{Materials and Methods}

The parental lines were planted in Misr Hytech seed Int. Co. research farm during 2017 season on twenty of February to make all possible crosses as straight and reciprocal hybrids to obtain ninety hybrids which sowed on 4/3/2018 for evaluation with 
their parents and two check varieties Aziad and New Eskandarani. The experimental design was randomized complete block design with three replicates each replicate consists of 102 genotypes divided into two ranges contains 51 genotypes for each range. Plot measurements were $4.0 \mathrm{~m}$ length, 0.85 $\mathrm{m}$ width and $0.50 \mathrm{~m}$ apart between plants therefore, the plot area was $3.4 \mathrm{~m}^{2}$.
Data were recorded for number of days to first female flower opening (DFFF), sex ratio as number of male to female flowers per plant, fruit weight (FW) $g$ , total soluble solids (TSS) \%, number of fruits per plant (NFP) and total yield per plant (TYP) g. Genetic statistical analysis was performed according to the method described by Gomez and Gomez (1984). LSD test were used for comparisons (Table 1).

Table 1. Sources of variance, degree of freedom and expected mean squares for F1 crosses.

\begin{tabular}{lll}
\hline \multicolumn{1}{c}{ Source of variance (S.O.V) } & D.f & E.M.S \\
\hline Blocks & $\mathrm{b}-1$ & $\delta_{\mathrm{e}}{ }^{2} \mathrm{ak}_{\mathrm{b}}{ }^{2}$ \\
\hline Genotypes & $\mathrm{a}-1$ & $\delta_{\mathrm{e}} \mathrm{bk}_{\mathrm{a}}{ }^{2}$ \\
\hline Parents & $\mathrm{p}-1$ & $\delta_{\mathrm{e}}{ }^{2} \mathrm{bk}_{\mathrm{p}}{ }^{2}$ \\
\hline Crosses & $\mathrm{c}-1$ & $\delta_{\mathrm{e}} \mathrm{bk}_{\mathrm{c}}{ }^{2}$ \\
\hline Parent vs. hybrids & $(\mathrm{a}-1)(\mathrm{b}-1)$ & $\delta_{\mathrm{e}}{ }^{2} \mathrm{bk}_{\mathrm{h}}{ }^{2}$ \\
\hline Error & & $\delta_{\mathrm{e}}{ }^{2}$ \\
\hline Where: & & \\
$\mathrm{b}=$ Number of replicates. & & \\
$\mathrm{a}=$ Number of genotypes. & & \\
$\mathrm{p}=$ Number of parent. & & \\
$\mathrm{c}=$ Number of hybrids. & & \\
$\mathrm{h}=$ Average heterosis. & & \\
$\mathrm{K}=$ Greek Kappa & & \\
$\delta_{\mathrm{e}}^{2}=$ Error variance & &
\end{tabular}

\section{Genetic parameters were:}

1- Heterosis as follow:

Mid parent heterosis $\%=\frac{\mathrm{F} 1-\mathrm{MP}}{\mathrm{MP}} \mathrm{X} 100$

Better parent heterosis $\%=\frac{\mathrm{F} 1-\mathrm{BP}}{\mathrm{BP}} \times 100$

Standard heterosis $\%=\frac{\text { F1-check }}{\text { check }} \times 100$

2- Phenotypic correlation coefficient estimated according to Steel and Torrie (1980) as follow:

$$
\mathrm{r}=\frac{\operatorname{Cov} \mathrm{xy}}{C \sqrt{V X . V Y}}
$$

Where: $\mathrm{x}$ and $\mathrm{y}$ are two characters

Cov. $\mathrm{Xy}=$ covariance between each pair of characters.

\section{Results and Discussions}

\section{Analysis of variance}

Results in Table 2 showed that mean squares for (D.F.F.F.) traits exhibited that significant or high significant for all types of variations. Moreover, sex ratio was high significant for all types of variations. Mean squares for fruit weight (F.W.) was significant or high significant for all types of variations except reciprocal effect. T.S.S recorded insignificant mean squares except replicates found high significant. Mean squares for (N.F.P.) and (T.Y.P.) characters were found high significant.

Table 2. Analysis of mean squares for yield and yield components.

\begin{tabular}{|c|c|c|c|c|c|c|c|}
\hline SOV & $\mathrm{df}$ & D.F.F.F. & Sex ratio $\hat{\delta} / Q$ & F.W.g & TSS \% & N.F.P. & T.Y.P.g \\
\hline rep & 2 & $6.94 *$ & $0.05 * *$ & 68.88 & $1.07 * *$ & 1.93 & 1937.13 \\
\hline genotypes & 99 & $15.31 * *$ & $0.21 * *$ & $126.33 * *$ & 0.13 & $16.78 * *$ & $153293.93 * *$ \\
\hline Parents & 9 & $24.29 * *$ & $1.09 * *$ & $222.45 * *$ & 0.1 & $35.60 * *$ & $122153.10 * *$ \\
\hline Crosses & 89 & $12.54 * *$ & $0.10 * *$ & $114.48 * *$ & 0.13 & $14.16^{* *}$ & $140177.87 * *$ \\
\hline Pxf1 & 1 & $180.86^{* *}$ & $1.53 * *$ & $316.38 * *$ & 0.01 & $80.46 * *$ & $1600890.75^{* *}$ \\
\hline Error & 198 & 1.98 & 0.01 & 22.56 & 0.1 & 1.98 & 8886.32 \\
\hline GCA & 9 & $27.46^{* *}$ & $0.48 * *$ & 324.17 ** & 0.04 & $25.09 * *$ & $188737.22 * *$ \\
\hline SCA & 45 & $4.09 * *$ & $0.05 * *$ & $18.13 *$ & 0.04 & $4.93 * *$ & $50741.94 * *$ \\
\hline Reciprocal & 45 & $1.64 *$ & $0.01 * *$ & 9.68 & 0.05 & $2.36 * *$ & $23926.17 * *$ \\
\hline Error & 198 & 0.66 & 0 & 7.52 & 0.03 & 0.66 & 2962.11 \\
\hline GCA/SCA & & 6.71 & 10.58 & 17.88 & 0.97 & 5.09 & 3.72 \\
\hline
\end{tabular}

\section{1- Flowering characters:}

\subsection{Number of days to first female flower:}

Results in Table (3) showed that the highest significant negative heterosis was recorded in the straight hybrid P1 X P6 (- 18.62\%)(- 20.64\%) and the lowest values were found in the hybrids P3 X P4 (-
$4.96 \%)$ and P2 X P6 (- 4.69\%) compared to mid and better parents, respectively.

Heterosis belonged to check varieties showed that the highest significant negative heterosis was recorded in the hybrid P1 X P6 (- 14.51\%)(- 14.65\%) and the highest positive values were found in the hybrid P6 X 
P8 $(6.62 \%)(6.46 \%)$ compared to check variety 1 and 2 , respectively. While, the lowest negative values were appeared in the hybrid P2 X P3 (- 5.05\%)($5.20 \%)$ relative to check 1 and 2 . In addition, the lowest positive value was noticed in the hybrid P3 X P7 $(5.05 \%)$. For reciprocals, the highest negative heterosis was exhibited in the hybrid P2 X P1 ($14.35 \%)$ over mid-parent and P5 X P3 (-16.16\%) over better parent, and the lowest negative values were appeared in the hybrids P10 X P8 (- 4.77\%) and P9 X P7 (- 5.21\%) compared to mid and better parents, respectively. For check varieties, the highest significant negative heterosis was found in the hybrid P4 X P1 (- 11.36\%)(- 11.50\%). While, the highest significant positive values were noticed in the hybrid P8 X P6 (6.62\%)(6.46\%). On the contrary, the lowest negative values were recorded in the hybrid P8 X P1 $(-4.89 \%)(-5.04 \%)$ against check 1 and 2, respectively. These data were presented by Hussien (2015), Hussien and Hamed (2015), El-Tahawey et al., (2015), Mohamed (2016b), Marxmathi et al., (2018 a).

Table 3. Estimation of heterosis percentage of $\mathrm{F} 1$ hybrids and their reciprocals relative to mid and better parents and two commercial checks for number of days to first female flower.

\begin{tabular}{|c|c|c|c|c|c|c|c|c|c|}
\hline F1 & Н. Мр & H. Bp & H. CV 1 & H. CV 2 & F1r & H. Мp & H. Bp & H. CV 1 & H. CV 2 \\
\hline P1XP2 & $-12.07 * *$ & $-13.32 * *$ & $-8.68 * *$ & $-8.82 * *$ & P2XP1 & $-14.35 * *$ & $-15.57 * *$ & $-11.04 * *$ & $-11.18 * *$ \\
\hline P1XP3 & $-12.80 * *$ & $-16.99 * *$ & $-5.99 *$ & $-6.14 * *$ & P3XP1 & $-10.17 * *$ & $-14.48 * *$ & -3.15 & -3.31 \\
\hline P1XP4 & $-9.66 * *$ & $-13.56^{* *}$ & $-11.51 * *$ & $-11.65 * *$ & P4XP1 & $-9.50 * *$ & $-13.41 * *$ & $-11.36^{* *}$ & $-11.50 * *$ \\
\hline P1XP5 & $-8.98 * *$ & $-9.33 * *$ & $-6.47 * *$ & $-6.61 * *$ & P5XP1 & $-7.75 * *$ & $-8.10^{* *}$ & $-5.21 *$ & $-5.35^{*}$ \\
\hline P1XP6 & $-18.62 * *$ & $-20.64 * *$ & $-14.51 * *$ & $-14.65 * *$ & P6XP1 & $-10.96 * *$ & $-13.18 * *$ & $-6.47 * *$ & $-6.61 * *$ \\
\hline P1XP7 & $-9.52 * *$ & $-12.17 * *$ & $-10.09 * *$ & $-10.24 * *$ & P7XP1 & $-10.48 * *$ & $-13.10 * *$ & $-11.04 * *$ & $-11.18 * *$ \\
\hline P1XP8 & $-16.17 * *$ & $-19.17 * *$ & $-10.88 * *$ & $-11.02 * *$ & P8XP1 & $-10.53 * *$ & $-13.73 * *$ & $-4.89 *$ & $-5.04 *$ \\
\hline P1XP9 & $-10.37 * *$ & $-11.40 * *$ & $-9.31 * *$ & $-9.45^{* *}$ & P9XP1 & -2.88 & -4.01 & -1.74 & -1.89 \\
\hline P1XP10 & $-6.83 * *$ & $-10.63 * *$ & $-8.52 * *$ & $-8.66^{* *}$ & P10XP1 & $-7.31 * *$ & $-11.09 * *$ & $-8.99 * *$ & $-9.13 * *$ \\
\hline P2XP3 & $-13.13 * *$ & $-16.16^{* *}$ & $-5.05 *$ & $-5.20 *$ & P3XP2 & $-8.23 * *$ & $-11.42 * *$ & 0.32 & 0.16 \\
\hline P2XP4 & -3.25 & $-8.68 * *$ & -3.79 & -3.94 & P4XP2 & -7.2 & $-12.43 * *$ & $-7.73 * *$ & $-7.87 * *$ \\
\hline P2XP5 & $-5.45^{*}$ & $-6.44 * *$ & -1.42 & -1.57 & P5XP2 & $-8.02 * *$ & $-8.98 * *$ & -4.1 & -4.25 \\
\hline P2XP6 & -3.63 & $-4.69^{*}$ & 2.68 & 2.52 & P6XP2 & $-4.96^{*}$ & $-6.00 * *$ & 1.26 & 1.10 \\
\hline P2XP7 & $-8.84 * *$ & $-12.72 * *$ & $-8.04 * *$ & $-8.19 * *$ & P7XP2 & $-8.99 * *$ & $-12.87 * *$ & $-8.20 * *$ & $-8.35^{* *}$ \\
\hline P2XP8 & -1.68 & -3.86 & $5.99 *$ & $5.83 *$ & P8XP2 & $-9.14 * *$ & $-11.16^{* *}$ & -2.05 & -2.20 \\
\hline P2XP9 & -2.30 & $-4.79 *$ & 0.32 & 0.16 & P9XP2 & -0.77 & -3.29 & 1.89 & 1.73 \\
\hline P2XP10 & -0.79 & $-6.14 * *$ & -1.10 & -1.26 & P10XP2 & -0.63 & $-5.99 * *$ & -0.95 & -1.10 \\
\hline P3XP4 & $-4.96 *$ & $-13.23 * *$ & -1.74 & -1.89 & P4XP3 & $-7.40 * *$ & $-15.46 * *$ & -4.26 & -4.41 \\
\hline P3XP5 & $-8.31 * *$ & $-12.40 * *$ & -0.79 & -0.94 & P5XP3 & $-12.24 * *$ & $-16.16^{* *}$ & $-5.05^{*}$ & $-5.20 *$ \\
\hline P3XP6 & $-7.07 * *$ & $-9.33 * *$ & 2.68 & 2.52 & P6XP3 & $-5.21 *$ & $-7.52 * *$ & $4.73 *$ & 4.57 \\
\hline P3XP7 & 0.23 & $-7.24 * *$ & $5.05 *$ & $4.88 *$ & P7XP3 & -2.03 & $-9.33 * *$ & 2.68 & 2.52 \\
\hline P3XP8 & $-5.72 * *$ & $-6.96 * *$ & $5.36^{*}$ & $5.20 *$ & P8XP3 & $-5.15^{*}$ & $-6.41 * *$ & $5.99 *$ & $5.83 *$ \\
\hline P3XP9 & $-7.99 * *$ & $-13.37 * *$ & -1.89 & -2.05 & P9XP3 & $-10.36 * *$ & $-15.60 * *$ & -4.42 & -4.57 \\
\hline P3XP10 & -0.76 & $-9.19 * *$ & 2.84 & 2.68 & P10XP3 & $-5.63^{*}$ & $-13.65 * *$ & -2.21 & -2.36 \\
\hline P4XP5 & $-6.17 * *$ & $-10.55^{* *}$ & $-7.73 * *$ & $-7.87 * *$ & P5XP4 & -3.45 & $-7.95 * *$ & $-5.05^{*}$ & $-5.20^{*}$ \\
\hline P4XP6 & $-7.05 * *$ & $-13.18 * *$ & $-6.47 * *$ & $-6.61 * *$ & P6XP4 & -3.92 & $-10.25^{* *}$ & -3.31 & -3.46 \\
\hline P4XP7 & $-6.15^{*}$ & $-7.53 * *$ & $-10.88 * *$ & $-11.02 * *$ & P7XP4 & -0.33 & -1.80 & $-5.36^{*}$ & $-5.51 *$ \\
\hline P4XP8 & -3.72 & $-11.02 * *$ & -1.89 & -2.05 & P8XP4 & 1.55 & $-6.15^{* *}$ & 3.47 & 3.31 \\
\hline P4XP9 & $-5.30^{*}$ & $-8.36^{* *}$ & $-8.36^{* *}$ & $-8.50 * *$ & P9XP4 & 0.73 & -2.52 & -2.52 & -2.68 \\
\hline P4XP10 & -1.77 & -2.01 & $-7.89 * *$ & $-8.03 * *$ & P10XP4 & $-5.13 *$ & $-5.37 *$ & $-11.04 * *$ & $-11.18^{* *}$ \\
\hline P5XP6 & -9.0 & -10.9 & & -4 & P6XP5 & -5. & -7.6 & -0 . & -0.63 \\
\hline P5XP7 & -1.50 & -4.7 & -1.74 & -1.89 & P7XP5 & -8.3 & -11 . & $-8.52 * *$ & $-8.66 * *$ \\
\hline P5XP8 & $-10.27 * *$ & $-13.16^{* *}$ & -4.26 & -4.41 & P8XP5 & $-4.95 *$ & $-8.01 * *$ & 1.42 & 1.26 \\
\hline P5XP9 & -2.02 & -3.52 & -0.47 & -0.63 & P9XP5 & -0.16 & -1.68 & 1.42 & 1.26 \\
\hline P5XP10 & -1.12 & $-5.50 *$ & -2.52 & -2.68 & P10XP5 & $-5.12 *$ & $-9.33 * *$ & $-6.47 * *$ & $-6.61 * *$ \\
\hline P6XP7 & -4.33 & $-9.37 * *$ & -2.37 & -2.52 & P7XP6 & $-5.26^{*}$ & $-10.25 * *$ & -3.31 & -3.46 \\
\hline P6XP8 & -2.17 & -3.29 & $6.62 * *$ & $6.46 * *$ & P8XP6 & -2.17 & -3.29 & $6.62 * *$ & $6.46 * *$ \\
\hline Р6XP9 & $-5.69 *$ & $-9.08 * *$ & -2.05 & -2.20 & P9XP6 & $-6.61 * *$ & $-9.96 * *$ & -3.00 & -3.15 \\
\hline P6XP10 & -1.49 & $-7.76^{* *}$ & -0.63 & -0.79 & P10XP6 & $-4.93 *$ & $-10.98 * *$ & -4.10 & -4.25 \\
\hline P7XP8 & $-9.47 * *$ & $-15.16^{* *}$ & $-6.47 * *$ & $-6.61 * *$ & P8XP7 & -1.68 & $-7.87 * *$ & 1.58 & 1.42 \\
\hline P7XP9 & $-5.22 *$ & $-6.94 * *$ & $-6.94 * *$ & $-7.09 * *$ & P9XP7 & -3.45 & $-5.21 *$ & $-5.21 *$ & $-5.35^{*}$ \\
\hline P7XP10 & -0.58 & -1.80 & $-5.36 *$ & $-5.51 *$ & P10XP7 & $-4.89 *$ & $-6.06^{*}$ & $-9.46 * *$ & $-9.61 * *$ \\
\hline P8XP9 & $-11.31 * *$ & $-14.49 * *$ & $-7.89 * *$ & $-8.03 * *$ & P9XP8 & $-6.30^{* *}$ & $-9.66 * *$ & -2.68 & -2.83 \\
\hline P8XP10 & -3.99 & $-10.10^{* *}$ & -3.15 & -3.31 & P10XP8 & $-4.77 *$ & $-10.83 * *$ & -3.94 & -4.09 \\
\hline P9XP10 & $7.64 * *$ & 4.42 & 4.42 & 4.25 & P10XP9 & -3.09 & $-5.99 *$ & $-5.99 *$ & $-6.14 * *$ \\
\hline
\end{tabular}




\subsection{Sex ratio $\lambda / q$}

Results in table (4) indicated that the highest significant negative heterosis was recorded in the straight hybrid P3 X P6 (- 62.38\%)(-73.97\%). While, the lowest negative values were appeared in the hybrid P1 X P8 (- 21.26\%)(- 22.07\%) over mid and better parents, respectively. the hybrid P6 X P8 gave the only highest significant positive heterosis $(23.02 \%)$ over mid-parent. For check varieties, the hybrid P2 X P3 shoed the highest significant positive heterosis (148.11\%). While, the hybrid P1 X P4 gave the only significant negative value $(-33.66 \%)$ over check1. In addition, the highest significant positive heterosis $(80.70 \%)$ was appeared in the hybrid P6 X P8 and the lowest positive value $(23.90 \%)$ was noticed in the hybrid P1 X P9). On the contrary, the highest significant negative value was showed in the hybrid P1 X P4 (- 49.54\%) and the lowest value was noticed in the hybrid P4 X P7 (-23.87\%) over check 2. relative to reciprocal hybrids, the highest significant positive heterosis was found in the hybrid P5 X P4 (55.13\%) and the lowest positive value was $(29.28 \%)$ in the hybrid P10 X P1. On the contrary, the highest significant negative heterosis was recorded in the hybrid P2 X P1 (- 52.24\%) and the lowest negative value $(-16.84 \%)$ was in the hybrid P8 X P6 over midparent. The highest significant negative heterosis was found in the hybrid P5 X P3 (-70.59\%) and the lowest negative value was found in hybrid P5 X P1 ($20.12 \%$ ), the only significant positive value was recorded in the hybrid P5 X P4 (30.63\%) better parent.

Table 4. Estimation of heterosis percentage of $\mathrm{F} 1$ hybrids and their reciprocals relative to mid and better parents and two commercial checks for sex ratio $\hat{\delta} / 9$.

\begin{tabular}{|c|c|c|c|c|c|c|c|c|c|}
\hline F1 & H. Мp & H. Bp & H. CV 1 & H. CV 2 & F1r & H. Мp & H. Вp & H. CV 1 & H. CV 2 \\
\hline P1XP2 & -9.61 & $-21.38 * *$ & $59.85 * *$ & 21.59 & $\mathrm{P} 2 \mathrm{XP} 1$ & $-52.24 * *$ & $-58.46 * *$ & -15.54 & $-35.76 * *$ \\
\hline P1XP3 & $-46.42 * *$ & $-66.56 * *$ & $102.52 * *$ & $54.04 * *$ & P3XP1 & $-51.79 * *$ & $-69.91 * *$ & $82.23 * *$ & $38.61 * *$ \\
\hline P1XP4 & $-41.90 * *$ & $-55.89 * *$ & $-33.66^{*}$ & $-49.54 * *$ & P4XP1 & $-31.21 *$ & $-47.77 * *$ & -21.45 & $-40.25 * *$ \\
\hline P1XP5 & -19.87 & $-29.57 * *$ & 5.93 & -19.43 & P5XP1 & -9.13 & $-20.12 *$ & 20.13 & -8.63 \\
\hline P1XP6 & $-50.34 * *$ & $-59.12 * *$ & -4.89 & $-27.66^{*}$ & P6XP1 & $-45.23 * *$ & $-54.91 * *$ & 4.91 & -20.20 \\
\hline P1XP7 & -18.21 & $-22.50 *$ & 16.56 & -11.34 & P7XP1 & $-32.28 * *$ & $-35.83 * *$ & -3.50 & $-26.60 *$ \\
\hline P1XP8 & $-21.26^{*}$ & $-22.07 *$ & 19.66 & -8.98 & P8XP1 & $-43.91 * *$ & $-44.49 * *$ & -14.77 & $-35.17 * *$ \\
\hline P1XP9 & -3.83 & -13.53 & $62.89 * *$ & $23.90 *$ & P9XP1 & $-24.92 * *$ & $-32.49 * *$ & 27.17 & -3.27 \\
\hline P1XP10 & -22.66 & $-36.66 * *$ & -4.74 & $-27.54 *$ & P10XP1 & $29.28 *$ & 5.88 & $59.23 * *$ & 21.12 \\
\hline P2XP3 & $-38.65 * *$ & $-59.03 * *$ & $148.11 * *$ & $88.72 * *$ & P3XP2 & $-49.77 * *$ & $-66.45 * *$ & $103.16^{* *}$ & $54.53 * *$ \\
\hline P2XP4 & -15.36 & $-41.45 * *$ & 19.04 & -9.45 & P4XP2 & $-37.87 * *$ & $-57.02 * *$ & -12.61 & $-33.53 * *$ \\
\hline P2XP5 & $-30.95 * *$ & $-46.12 * *$ & 9.55 & -16.67 & P5XP2 & $-40.55 * *$ & $-53.61 * *$ & -5.68 & $-28.26^{*}$ \\
\hline P2XP6 & $-50.73 * *$ & $-53.84 * *$ & 7.41 & -18.30 & P6XP2 & $-53.61 * *$ & $-56.53 * *$ & 1.13 & $-23.07 *$ \\
\hline P2XP7 & $-28.47 * *$ & $-40.55 * *$ & 20.86 & -8.07 & P7XP2 & -2.95 & $-19.35 * *$ & $63.98 * *$ & $24.73 *$ \\
\hline P2XP8 & $-38.94 * *$ & $-46.41 * *$ & 8.95 & -17.13 & P8XP2 & $-31.66 * *$ & $-40.03 * *$ & 21.93 & -7.25 \\
\hline P2XP9 & $-26.31 * *$ & $-29.02 * *$ & $44.31 * *$ & 9.77 & P9XP2 & -4.62 & -8.12 & $86.80 * *$ & $42.09 * *$ \\
\hline P2XP10 & -15.18 & $-37.58 * *$ & 26.91 & -3.47 & P10XP2 & 0.30 & $-26.18 * *$ & $50.08 * *$ & 14.16 \\
\hline P3XP4 & $-30.11 * *$ & $-60.55 * *$ & $138.87 * *$ & $81.69 * *$ & P4XP3 & $-47.47 * *$ & $-70.35 * *$ & $79.54 * *$ & $36.56 * *$ \\
\hline P3XP5 & $-44.81 * *$ & $-67.21 * *$ & $98.58 * *$ & $51.05 * *$ & P5XP3 & $-50.50 * *$ & $-70.59 * *$ & $78.08 * *$ & $35.46^{* *}$ \\
\hline P3XP6 & $-62.38 * *$ & $-73.97 * *$ & $57.66 * *$ & 19.92 & P6XP3 & $-49.50 * *$ & $-65.05 * *$ & $111.64 * *$ & $60.98 * *$ \\
\hline P3XP7 & $-52.64 * *$ & $-71.06 * *$ & $75.28 * *$ & $33.32 * *$ & P7XP3 & $-27.75 * *$ & $-55.84 * *$ & $167.39 * *$ & $103.39 * *$ \\
\hline P3XP8 & $-46.41 * *$ & $-66.41 * *$ & $103.41 * *$ & $54.73 * *$ & P8XP3 & $-37.60 * *$ & $-60.89 * *$ & $136.83 * *$ & $80.14 * *$ \\
\hline P3XP9 & $-42.65 * *$ & $-62.41 * *$ & $127.65 * *$ & $73.16 * *$ & P9XP3 & $-45.46 * *$ & $-64.25 * *$ & $116.49 * *$ & $64.67 * *$ \\
\hline P3XP10 & $-42.25 * *$ & $-66.55 * *$ & $102.55 * *$ & $54.06 * *$ & P10XP3 & $-36.99 * *$ & $-63.50 * *$ & $121.02 * *$ & $68.12 * *$ \\
\hline P4XP5 & -2.86 & -18.20 & -6.76 & $-29.08 *$ & P5XP4 & $55.13 * *$ & $30.63^{*}$ & $48.90 * *$ & 13.26 \\
\hline P4XP6 & $-39.97 * *$ & $-59.92 * *$ & -6.76 & $-29.07 *$ & P6XP4 & -7.54 & $-38.27 * *$ & $43.62 * *$ & 9.24 \\
\hline P4XP7 & -5.85 & $-25.66 *$ & 0.08 & $-23.87 *$ & P7XP4 & -8.62 & $-27.84 *$ & -2.86 & $-26.11 *$ \\
\hline P4XP8 & 1.54 & $-23.44 *$ & 17.55 & -10.59 & P8XP4 & 23.02 & -7.25 & $42.42 * *$ & 8.33 \\
\hline P4XP9 & -18.31 & $-42.25 * *$ & 8.79 & -17.25 & P9XP4 & 7.93 & $-23.69 * *$ & $43.74 * *$ & 9.34 \\
\hline P4XP10 & -8.51 & -17.08 & -20.43 & $-39.48 * *$ & P10XP4 & -29.5 & $-36.10 *$ & $-38.68 *$ & $-53.36 * *$ \\
\hline P5XP6 & $-38.25 * *$ & $-54.00 * *$ & 7.04 & -18.58 & P6XP5 & $-27.40 * *$ & $-45.92 * *$ & 25.84 & -4.28 \\
\hline P5XP7 & -22.14 & $-28.11 *$ & -3.21 & $-26.38 *$ & P7XP5 & -21.21 & $-27.25 *$ & -2.06 & $-25.50 *$ \\
\hline P5XP8 & -5.09 & -17.31 & 26.96 & -3.43 & P8XP5 & 7.24 & -6.57 & $43.46 * *$ & 9.12 \\
\hline P5XP9 & 0.13 & $-19.64 *$ & $51.38 * *$ & 15.15 & P9XP5 & -14.69 & $-31.53 * *$ & 28.97 & -1.90 \\
\hline P5XP10 & -24.28 & $-30.27 *$ & -20.51 & $-39.54 * *$ & P10XP5 & -18.69 & -25.13 & -14.65 & $-35.08 * *$ \\
\hline P6XP7 & $-42.15 * *$ & $-54.34 * *$ & 6.23 & -19.20 & P7XP6 & $-48.13 * *$ & $-59.06 * *$ & -4.74 & $-27.54 *$ \\
\hline P6XP8 & $23.02 * *$ & 2.10 & $137.57 * *$ & $80.70 * *$ & P8XP6 & $-16.84 *$ & $-30.98 * *$ & $60.59 * *$ & 22.15 \\
\hline P6XP9 & $-33.62 * *$ & $-39.94 * *$ & $39.75 * *$ & 6.30 & Р9XP6 & $-49.58 * *$ & $-54.38 * *$ & 6.14 & -19.26 \\
\hline P6XP10 & $-48.58 * *$ & $-63.68 * *$ & -15.50 & $-35.73 * *$ & P10XP6 & $-38.99 * *$ & $-56.92 * *$ & 0.25 & $-23.75^{*}$ \\
\hline P7XP8 & 6.64 & 0.07 & $53.65^{* *}$ & 16.88 & P8XP7 & -6.16 & -11.94 & $35.21 *$ & 2.85 \\
\hline P7XP9 & -13.88 & $-26.16 * *$ & $39.09 * *$ & 5.80 & P9XP7 & $-28.01 * *$ & $-38.28 * *$ & 16.26 & -11.57 \\
\hline P7XP10 & 5.28 & -9.84 & 21.37 & -7.68 & P10XP7 & -12.76 & $-25.29 *$ & 0.58 & $-23.50 *$ \\
\hline P8XP9 & $-55.22 * *$ & $-59.49 * *$ & -5.74 & $-28.30 *$ & P9XP8 & $-48.48 * *$ & $-53.39 * *$ & 8.46 & -17.5 \\
\hline P8XP10 & $-33.39 * *$ & $-52.96 * *$ & 9.45 & -16.75 & P10XP8 & $-33.63 * *$ & $-53.13 * *$ & 9.05 & -17.05 \\
\hline P9XP10 & -14.59 & $-35.54 * *$ & 21.42 & -7.64 & P10XP9 & -11.57 & $-33.26 * *$ & 25.72 & -4.37 \\
\hline
\end{tabular}


Heterosis belonged to check varieties, the highest significant positive heterosis was recorded in the hybrid P7 X P3 (167.39\%)(103.39\%) over check 1 and 2 . While, the only significant negative value was in the hybrid P10 X P4 (- 38.68\%) over check 1. On the contrary, the highest significant negative heterosis over check 2 was appeared in the hybrid P10 X P4 ($53.36 \%)$ and lowest negative value was in the hybrid P10 X P7 (- 23.50\%). These data were presented by Obiadalla-Ali (2006), Tamil et al., (2012), Mohamed (2016b), Marxmathi et al., (2018 a).

\section{2- Fruit characters:}

\subsection{Fruit weight (g)}

Table 5. Estimation of heterosis percentage of F1 hybrids and their reciprocals relative to mid and better parents and two commercial checks for fruit weight $(\mathrm{g})$.

\begin{tabular}{|c|c|c|c|c|c|c|c|c|c|}
\hline F1 & Н. Мр & H. Bp & H. CV 1 & H. CV 2 & F1r & Н. Мp & H. Bp & H. CV 1 & H. CV 2 \\
\hline P1XP2 & $11.72 * *$ & $10.75 * *$ & $8.21 *$ & $8.87 *$ & P2XP1 & $12.93 * *$ & $11.95 * *$ & $9.38 *$ & $10.05^{*}$ \\
\hline P1XP3 & 3.06 & -3.76 & $8.36 *$ & $9.02 *$ & P3XP1 & 2.36 & -4.41 & 7.62 & $8.28 *$ \\
\hline P1XP4 & -0.55 & -2.16 & -4.41 & -3.82 & P4XP1 & 3.12 & 1.46 & -0.87 & -0.27 \\
\hline P1XP5 & -1.12 & -3.31 & -5.53 & -4.95 & P5XP1 & $8.56^{*}$ & 6.16 & 3.71 & 4.35 \\
\hline P1XP6 & $11.87 * *$ & 5.38 & 2.96 & 3.59 & P6XP1 & $12.13 * *$ & 5.62 & 3.19 & 3.82 \\
\hline P1XP7 & 3.89 & -2.07 & -4.32 & -3.73 & P7XP1 & 6.92 & 0.79 & -1.53 & -0.93 \\
\hline P1XP8 & 2.60 & -5.31 & $9.39 *$ & $10.06 *$ & P8XP1 & -4.04 & $-11.45^{* *}$ & 2.31 & 2.93 \\
\hline P1XP9 & $13.00 * *$ & 7.61 & 5.13 & 5.78 & P9XP1 & $18.19 * *$ & $12.56 * *$ & $9.97 *$ & $10.64 * *$ \\
\hline P1XP10 & 4.17 & 0.88 & -1.44 & -0.84 & P10XP1 & -2.74 & -5.82 & $-7.98 *$ & -7.42 \\
\hline P2XP3 & -1.89 & $-9.11 * *$ & 2.33 & 2.96 & P3XP2 & -2.92 & $-10.07 * *$ & 1.25 & 1.87 \\
\hline P2XP4 & 4.72 & 3.93 & -0.22 & 0.39 & P4XP2 & -2.73 & -3.47 & -7.32 & -6.76 \\
\hline P2XP5 & 2.35 & 0.94 & -3.09 & -2.49 & P5XP2 & -0.34 & -1.70 & -5.63 & -5.05 \\
\hline P2XP6 & 6.29 & 0.95 & -3.08 & -2.49 & P6XP2 & 0.00 & -5.02 & $-8.82 *$ & $-8.26 *$ \\
\hline P2XP7 & 2.03 & -3.03 & -6.9 & -6.33 & P7XP2 & 8.22 & 2.86 & -1.25 & -0.65 \\
\hline P2XP8 & -2.38 & $-10.63 * *$ & 3.25 & 3.88 & P8XP2 & 4.19 & -4.61 & $10.20 * *$ & $10.88 * *$ \\
\hline P2XP9 & 2.35 & -1.72 & -5.64 & -5.07 & P9XP2 & 2.17 & -1.89 & -5.81 & -5.23 \\
\hline P2XP10 & 3.05 & 0.64 & -3.37 & -2.78 & P10XP2 & 3.45 & 1.03 & -3.00 & -2.41 \\
\hline P3XP4 & -2.39 & $-10.21 * *$ & 1.10 & 1.72 & P4XP3 & $-9.61 *$ & $-16.85^{* *}$ & -6.38 & -5.81 \\
\hline P3XP5 & -5.14 & $-13.23 * *$ & -2.31 & -1.71 & P5XP3 & 0.33 & $-8.23 *$ & 3.33 & 3.96 \\
\hline P3XP6 & $7.93 *$ & -4.64 & 7.37 & $8.03 *$ & P6XP3 & 4.27 & $-7.87 *$ & 3.73 & 4.36 \\
\hline P3XP7 & -4.46 & $-15.53 * *$ & -4.90 & -4.31 & P7XP3 & -1.04 & $-12.50 * *$ & -1.49 & -0.89 \\
\hline P3XP8 & 4.60 & 3.27 & $19.31 * *$ & $20.04 * *$ & P8XP3 & 4.30 & 2.98 & $18.97 * *$ & $19.70 * *$ \\
\hline P3XP9 & -1.20 & $-11.82 * *$ & -0.72 & -0.11 & P9XP3 & 5.96 & -5.43 & 6.48 & 7.13 \\
\hline P3XP10 & 3.79 & -5.92 & 5.92 & 6.57 & P10XP3 & -0.70 & $-9.99 * *$ & 1.34 & 1.96 \\
\hline P4XP5 & -0.14 & -0.76 & -6.17 & -5.60 & P5XP4 & 7.02 & 6.36 & 0.56 & 1.18 \\
\hline P4XP6 & $10.58 *$ & 5.79 & 0.02 & 0.63 & P6XP4 & 4.12 & -0.39 & -5.82 & -5.24 \\
\hline P4XP7 & -2.27 & -6.43 & $-11.53 * *$ & $-10.99 * *$ & P7XP4 & 1.02 & -3.28 & $-8.55 *$ & $-8.00 *$ \\
\hline P4XP8 & 2.06 & $-7.21 *$ & 7.21 & $7.86^{*}$ & P8XP4 & 0.52 & $-8.61 *$ & 5.59 & 6.23 \\
\hline P4XP9 & 1.72 & -1.59 & -6.96 & -6.39 & P9XP4 & $17.41 * *$ & $13.58 * *$ & 7.38 & $8.04 *$ \\
\hline P4XP10 & -1.00 & -2.58 & $-7.89 *$ & -7.33 & P10XP4 & -2.51 & -4.07 & $-9.30 *$ & $-8.75 *$ \\
\hline P5XP6 & 6.07 & 2.09 & -4.67 & -4.09 & P6XP5 & $8.66^{*}$ & 4.58 & -2.34 & -1.75 \\
\hline P5XP7 & 1.28 & -2.45 & $-8.91 *$ & $-8.36 *$ & P7XP5 & 3.05 & -0.74 & -7.32 & -6.75 \\
\hline P5XP8 & 5.33 & -4.77 & $10.02 *$ & $10.70 * *$ & P8XP5 & -1.25 & $-10.72 * *$ & 3.15 & 3.78 \\
\hline P5XP9 & 5.52 & 2.70 & -4.10 & -3.51 & P9XP5 & 0.39 & -2.30 & $-8.77 *$ & $-8.21 *$ \\
\hline P5XP10 & 0.65 & -0.35 & -6.95 & -6.38 & P10XP5 & 7.00 & 5.94 & -1.08 & -0.47 \\
\hline P6XP7 & $12.01 * *$ & $11.92 * *$ & -3.19 & -2.60 & P7XP6 & 8.86 & 8.77 & -5.92 & -5.34 \\
\hline P6XP8 & $9.00 *$ & -4.76 & $10.03 *$ & $10.71 * *$ & P8XP6 & $9.73 *$ & -4.12 & $10.77 * *$ & $11.45^{* *}$ \\
\hline P6XP9 & $9.21 *$ & 7.96 & -4.58 & -4.00 & P9XP6 & $17.75 * *$ & $16.40 * *$ & 2.88 & 3.51 \\
\hline P6XP10 & 5.36 & 2.39 & -6.29 & -5.71 & P10XP6 & $8.87 *$ & 5.80 & -3.17 & -2.57 \\
\hline P7XP8 & 5.05 & $-8.15^{*}$ & 6.11 & 6.76 & P8XP7 & $10.18 * *$ & -3.67 & $11.29 * *$ & $11.97 * *$ \\
\hline P7XP9 & 6.81 & 5.67 & -6.61 & -6.04 & P9XP7 & $9.94 *$ & 8.77 & -3.87 & -3.28 \\
\hline P7XP10 & 8.19 & 5.22 & -3.70 & -3.11 & P10XP7 & 0.49 & -2.27 & $-10.55 * *$ & $-10.01 *$ \\
\hline P8XP9 & $34.36 * *$ & $32.82 * *$ & $17.39 * *$ & $18.11 * *$ & P9XP8 & $30.70 * *$ & $29.21 * *$ & $14.20 * *$ & $14.90 * *$ \\
\hline P8XP10 & $23.61 * *$ & $20.12 * *$ & $9.94 *$ & $10.61 * *$ & P10XP8 & $28.57 * *$ & $24.94 * *$ & $14.35 * *$ & $15.05 * *$ \\
\hline P9XP10 & 6.09 & 4.27 & -4.57 & -3.99 & P10XP9 & -0.72 & -2.42 & $-10.69 * *$ & $-10.15 *$ \\
\hline
\end{tabular}

Data from table (5) exhibited that only positive
ffects, the highest significant positive heterosis was in the straight hybrid P8 X P9 (34.36\%)(32.82\%) over mid and better parent, respectively. The highest significant negative heterotic effect was in the hybrid P3 X P7 (-15.53\%) and the lowest value was in the hybrid P4 X P8 (- 7.21\%) over better parent. Heterosis related to check varieties revealed that the highest significant positive effects were in the hybrid P3 X P8 $(19.31 \%)(20.04 \%)$ over check 1 and 2, respectively. While, the lowest positive value was in the hybrid P1 X P2 (8.21\%) over check 1. While, the hybrid P4 X P8 $(7.86 \%)$ over check 2 . 
In addition, some significant or high significant negative effects were detected compared to check 1 and 2 . In respect to reciprocals, the highest significant positive heterosis was detected in the hybrid P9 X P8 $(30.70 \%)(29.21 \%)$ over mid and better parents, respectively. While, significant and high significant positive lowest values were found in the hybrids P5 X P1 $(8.56 \%)$ and P9 X P6 (16.40\%) over mid and better parents, respectively. Only one significant negative value was recorded in the hybrid P4 X P3 (- 9.61over mid-parent. On the other hand, some significant or high significant negative values were appeared over better parent. Heterosis related to check varieties exhibited that the highest significant positive heterosis was found in the hybrid P8 X P3 (18.97\%)(19.70\%) over check 1 and 2 , respectively. The significant positive lowest value was noticed in the hybrids $\mathrm{P} 2 \mathrm{X}$ P1 (12.93\%) and P9 X P4 (8.04\%) over check 1 and 2 , respectively. In addition some significant or high significant negative values were obtained over check 1 and 2. These data were presented by Mohamed (2016a) , Marxmathi et al., (2018a), Restrepo (2018), Hikal and Abdein (2018), Gad Allah (2019).

\subsection{Total soluble solids (TSS)}

Results illustrated in table (6) revealed that significant negative heterosis was recorded in the straight hybrid P2 X P5 (- 7.21\%)(- 8.04\%) over mid and better parents, respectively. The only significant positive effect was in the hybrid P4 X P8 (7.64\%) over midparents. While, another significant negative value was appeared in the hybrid P2 X P9 (- 7.38\%) over better parent. The rest of hybrids did not show any significant effects. For check variety 1, only four hybrids showed significant positive values the highest value was in the hybrid P4 X P9 (8.74\%) and the lowest value was $(7.30 \%)$ in the hybrid P6 X P8. On the contrary, no heterotic effects were found over check 2. In respect to reciprocals, the hybrid P8 XP1 showed high significant or significant positive heterosis $(9.90 \%)(8.77 \%)$ over mid and better parents. In addition, few hybrids showed significant or high significant positive or negative over mid and better parents. For check variety 1 , the highest significant positive value was in the hybrids P8 X P1 (11.17\%) and P10 X P1 (9.85\%). In addition five hybrids gave significant positive values. Regard to check 2, only two hybrids showed significant positive and high significant negative values over check 2 viz., P8 x P1 (8.18\%) and P4 X P2 (-9.36\%), respectively. The rest of hybrids did not show any heterotic effects. These data were presented by Marxmathi et al., (2018a), Hikal and Abdein (2018), Gad Allah (2019).

\section{Yield characters}

\subsection{Number of fruits per plant}

Data from table (7) reported that the highest significant positive heterosis was found in the straight hybrid P1 X P3 (42.33\%) and the significant positive lowest value was in the hybrid P2 X P10 (12.61\%). In addition, only two hybrids showed high significant negative values and some hybrids showed significant or high significant positive values over mid-parent. The highest significant positive heterosis over better parent was found in the hybrid P1 X P7 (32.58\%) and the significant positive lowest value was in the hybrid P6 X P10 (11.19\%). In addition some hybrids showed significant or high significant positive or negative values over better parent. Belonging to check varieties, the highest significant positive value was in the hybrid P4 X P10 (19.54\%) and the significant positive lowest value was in the hybrid P4 X P7 $(11.88 \%)$. In addition, some hybrids showed significant or high significant positive or negative over better parent. For check varieties, the highest significant positive heterosis was found in the hybrid P4 X P10 (19.54\%)(35.65\%) over check 1 and 2. While, the significant positive lowest values was in hybrids P4 X P7 (11.88\%) and P1 X P5 (14.78\%) over check 1 and 2, respectively. In addition, some hybrids showed different levels of heterosis over the two checks. In respect to reciprocal crosses, the highest significant heterosis was appeared in the hybrids P3 X P1 $(47.85 \%)$ and P2 X P1 (32.42\%) over mid and better parents, respectively. While, the significant positive lowest values was found in the hybrids P5 X P7 (13.81\%) and P9 X P8 (12.45\%) over mid and better parents, respectively. In addition, some hybrids showed significant or high significant positive or negative values. Relative to the checks, the highest significant positive values were found in the hybrid P10 X P8 (28.74\%)(46.09\%) over check variety 1 and 2 , respectively. Moreover, some hybrids showed different levels of heterosis over the two checks. These data were presented by Marie et al., (2012), Hatem et al., (2013), Othman (2016), Chaudhari et al. (2017), Marxmathi et al., (2018a), Elsharkawy et al. (2018), Hikal and Abdein (2018), Gad Allah (2019). 
Table 6. Estimation of heterosis percentage of F1 hybrids and their reciprocals relative to mid and better parents and two commercial checks for TSS (\%).

\begin{tabular}{|c|c|c|c|c|c|c|c|c|c|}
\hline F1 & H. Mp & H. Bp & H. CV 1 & H. CV 2 & F1r & H. Mp & H. Bp & H. CV 1 & H. CV 2 \\
\hline P1XP2 & 2.09 & 1.17 & 5.31 & 2.48 & P2XP1 & -0.27 & -1.17 & 2.88 & 0.11 \\
\hline P1XP3 & -3.73 & -3.88 & -1.44 & -4.09 & P3XP1 & 3.62 & 3.45 & 6.08 & 3.23 \\
\hline P1XP4 & -3.70 & -4.22 & -2.10 & -4.74 & P4XP1 & 1.52 & 0.97 & 3.21 & 0.43 \\
\hline P1XP5 & -1.38 & -3.13 & 2.65 & -0.11 & P5XP1 & -1.28 & -3.03 & 2.77 & 0.00 \\
\hline P1XP6 & 0.98 & 0.00 & 2.21 & -0.54 & P6XP1 & 0.22 & -0.76 & 1.44 & -1.29 \\
\hline P1XP7 & -2.82 & -4.40 & 1.00 & -1.72 & P7XP1 & 0.27 & -1.36 & 4.20 & 1.40 \\
\hline P1XP8 & 2.46 & 1.41 & 3.65 & 0.86 & P8XP1 & $9.90 * *$ & $8.77^{*}$ & $11.17 * *$ & $8.18^{*}$ \\
\hline P1XP9 & -2.32 & -4.92 & 2.65 & -0.11 & P9XP1 & -2.21 & -4.82 & 2.77 & 0.00 \\
\hline P1XP10 & -1.43 & -3.25 & -1.11 & -3.77 & P10XP1 & $9.48 * *$ & $7.47 *$ & $9.85^{* *}$ & 6.89 \\
\hline P2XP3 & -3.75 & -4.46 & -0.55 & -3.23 & P3XP2 & -4.07 & -4.78 & -0.88 & -3.55 \\
\hline P2XP4 & 0.38 & -1.06 & 2.99 & 0.22 & P4XP2 & $-9.22 * *$ & $-10.52 * *$ & -6.86 & $-9.36^{* *}$ \\
\hline P2XP5 & $-7.21 *$ & $-8.04 *$ & -2.54 & -5.17 & P5XP2 & 0.47 & -0.42 & 5.53 & 2.69 \\
\hline P2XP6 & 2.22 & 0.32 & 4.42 & 1.61 & P6XP2 & -5.04 & -6.80 & -2.99 & -5.60 \\
\hline P2XP7 & -1.58 & -2.30 & 3.21 & 0.43 & P7XP2 & -0.63 & -1.36 & 4.20 & 1.40 \\
\hline P2XP8 & 4.88 & 2.87 & 7.08 & 4.20 & P8XP2 & 3.58 & 1.59 & 5.75 & 2.91 \\
\hline P2XP9 & -5.69 & $-7.38 *$ & 0.00 & -2.69 & P9XP2 & -0.68 & -2.46 & 5.31 & 2.48 \\
\hline P2XP10 & 1.26 & -1.49 & 2.54 & -0.22 & P10XP2 & 3.28 & 0.48 & 4.59 & 1.78 \\
\hline P3XP4 & -5.59 & -6.26 & -3.87 & -6.46 & P4XP3 & 4.18 & 3.45 & 6.08 & 3.23 \\
\hline P3XP5 & -1.33 & -2.92 & 2.88 & 0.11 & P5XP3 & 0.27 & -1.36 & 4.54 & 1.72 \\
\hline P3XP6 & 5.07 & 3.88 & 6.53 & 3.66 & P6XP3 & 0.82 & -0.32 & 2.21 & -0.54 \\
\hline P3XP7 & 2.44 & 0.94 & 6.64 & 3.77 & P7XP3 & -1.59 & -3.04 & 2.43 & -0.32 \\
\hline P3XP8 & -2.40 & -3.56 & -1.11 & -3.77 & P8XP3 & 3.28 & 2.05 & 4.65 & 1.83 \\
\hline Р3XP9 & 2.89 & 0.31 & $8.30^{*}$ & 5.38 & P9XP3 & -3.00 & -5.43 & 2.10 & -0.65 \\
\hline P3XP10 & 3.58 & 1.51 & 4.09 & 1.29 & P10XP3 & 4.13 & 2.05 & 4.65 & 1.83 \\
\hline P4XP5 & 0.21 & -2.09 & 3.76 & 0.97 & P5XP4 & -6.62 & $-8.77 *$ & -3.32 & -5.92 \\
\hline P4XP6 & 2.64 & 2.19 & 3.32 & 0.54 & P6XP4 & -0.44 & -0.88 & 0.22 & -2.48 \\
\hline P4XP7 & -2.62 & -4.71 & 0.66 & -2.05 & P7XP4 & 1.44 & -0.73 & 4.87 & 2.05 \\
\hline P4XP8 & $7.64^{*}$ & 7.11 & $8.30 *$ & 5.38 & P8XP4 & 3.79 & 3.28 & 4.42 & 1.61 \\
\hline P4XP9 & 4.02 & 0.72 & $8.74 *$ & 5.81 & P9XP4 & -4.55 & $-7.58^{*}$ & -0.22 & -2.91 \\
\hline P4XP10 & 4.55 & 3.17 & 4.31 & 1.51 & P10XP4 & $7.76^{*}$ & 6.35 & $7.52 *$ & 4.63 \\
\hline P5XP6 & -3.86 & -6.47 & -0.88 & -3.55 & P6XP5 & -1.29 & -3.97 & 1.77 & -0.97 \\
\hline P5XP7 & -5.18 & -5.32 & 0.33 & -2.37 & P7XP5 & 2.04 & 1.88 & $7.96^{*}$ & 5.06 \\
\hline P5XP8 & 0.81 & -1.98 & 3.87 & 1.08 & P8XP5 & 1.23 & -1.57 & 4.31 & 1.51 \\
\hline Р5XP9 & -1.86 & -2.77 & 4.98 & 2.15 & P9XP5 & 0.10 & -0.82 & 7.08 & 4.20 \\
\hline P5XP10 & 3.03 & -0.63 & 5.31 & 2.48 & P10XP5 & 5.41 & 1.67 & $7.74 *$ & 4.84 \\
\hline Р6XP7 & -1.88 & -4.40 & 1.00 & -1.72 & P7XP6 & -0.27 & -2.83 & 2.65 & -0.11 \\
\hline P6XP8 & 7.12 & 7.06 & $7.30 *$ & 4.41 & P8XP6 & $7.56^{*}$ & $7.51^{*}$ & $7.74^{*}$ & 4.84 \\
\hline Р6XP9 & -2.98 & -6.45 & 1.00 & -1.72 & P9XP6 & $-7.33^{*}$ & $-10.66^{* *}$ & -3.54 & -6.14 \\
\hline P6XP10 & -2.67 & -3.53 & -3.32 & -5.92 & P10XP6 & 7.02 & 6.07 & 6.31 & 3.44 \\
\hline P7XP8 & 1.51 & -1.15 & 4.42 & 1.61 & P8XP7 & -2.90 & -5.45 & -0.11 & -2.80 \\
\hline Р7XP9 & -1.71 & -2.77 & 4.98 & 2.15 & P9XP7 & -5.85 & $-6.86^{*}$ & 0.55 & -2.15 \\
\hline P7XP10 & 1.57 & -1.88 & 3.65 & 0.86 & P10XP7 & -1.25 & -4.61 & 0.77 & -1.94 \\
\hline Р8XР9 & -2.34 & -5.84 & 1.66 & -1.08 & P9XP8 & -4.78 & $-8.20 *$ & -0.88 & -3.55 \\
\hline P8XP10 & 2.67 & 1.77 & 1.99 & -0.75 & P10XP8 & 4.90 & 3.97 & 4.20 & 1.40 \\
\hline P9XP10 & 2.04 & -2.46 & 5.31 & 2.48 & P10XP9 & 5.14 & 0.51 & $8.52 *$ & 5.60 \\
\hline
\end{tabular}


Table 7. Estimation of heterosis percentage of F1 hybrids and their reciprocals relative to mid and better parents and two commercial checks for number of fruits/plant.

\begin{tabular}{|c|c|c|c|c|c|c|c|c|c|}
\hline F1 & Н. Мр & H. Bp & H. CV 1 & H. CV 2 & F1r & H. Мp & H. Bp & H. CV 1 & H. CV 2 \\
\hline P1XP2 & $29.67 * *$ & $23.74 * *$ & 3.83 & $17.83 * *$ & P2XP1 & $38.76 * *$ & $32.42 * *$ & 11.11 & $26.09 * *$ \\
\hline P1XP3 & $42.33 * *$ & 5.94 & -11.11 & 0.87 & P3XP1 & $47.85^{* *}$ & 10.05 & -7.66 & 4.78 \\
\hline P1XP4 & $20.08 * *$ & 4.76 & $18.01 * *$ & $33.91 * *$ & P4XP1 & $18.13 * *$ & 3.06 & $16.09 * *$ & $31.74 * *$ \\
\hline P1XP5 & 10.92 & 2.72 & 1.15 & $14.78 *$ & P5XP1 & -5.88 & $-12.84 *$ & $-14.18 *$ & -2.61 \\
\hline P1XP6 & 10.43 & 5.39 & -2.68 & 10.43 & P6XP1 & $20.00 * *$ & $14.52 *$ & 5.75 & $20.00 * *$ \\
\hline P1XP7 & $33.18 * *$ & $32.58 * *$ & $12.26^{*}$ & $27.39 * *$ & P7XP1 & $16.82 *$ & $16.29 *$ & -1.53 & 11.74 \\
\hline P1XP8 & $29.30 * *$ & $26.94 * *$ & 6.51 & $20.87 * *$ & P8XP1 & $20.00 * *$ & $17.81 * *$ & -1.15 & 12.17 \\
\hline P1XP9 & 10.43 & 6.39 & -10.73 & 1.30 & P9XP1 & 2.37 & -1.37 & $-17.24 * *$ & -6.09 \\
\hline P1XP10 & 11.29 & -0.36 & 5.75 & $20.00 * *$ & P10XP1 & -8.47 & $-18.05 * *$ & $-13.03 *$ & -1.30 \\
\hline P2XP3 & 13.07 & -13.07 & $-33.72 * *$ & $-24.78 * *$ & P3XP2 & $43.79 * *$ & 10.55 & $-15.71 * *$ & -4.35 \\
\hline P2XP4 & 5.07 & $-11.90 *$ & -0.77 & 12.61 & P4XP2 & 5.88 & $-11.22 *$ & 0.00 & $13.48 *$ \\
\hline P2XP5 & 8.33 & -3.89 & -5.36 & 7.39 & P5XP2 & 10.96 & -1.56 & -3.07 & 10.00 \\
\hline P2XP6 & 2.27 & -6.64 & $-13.79 *$ & -2.17 & P6XP2 & $36.82 * *$ & $24.90 * *$ & $15.33 * *$ & $30.87 * *$ \\
\hline P2XP7 & $26.67 * *$ & $20.36 * *$ & 1.92 & $15.65^{*}$ & P7XP2 & $17.14 *$ & 11.31 & -5.75 & 6.96 \\
\hline P2XP8 & $20.00 * *$ & $16.59 *$ & -5.75 & 6.96 & P8XP2 & $32.20 * *$ & $28.44 * *$ & 3.83 & $17.83 * *$ \\
\hline P2XP9 & $24.88 * *$ & $23.65^{* *}$ & -3.83 & 9.13 & P9XP2 & $19.90 * *$ & $18.72 *$ & -7.66 & 4.78 \\
\hline P2XP10 & $12.61 *$ & -3.25 & 2.68 & $16.52 *$ & P10XP2 & 0.00 & $-14.08 * *$ & -8.81 & 3.48 \\
\hline P3XP4 & $18.20 *$ & $-19.39 * *$ & -9.20 & 3.04 & P4XP3 & 3.24 & $-29.59 * *$ & $-20.69 * *$ & -10.00 \\
\hline P3XP5 & $40.11 * *$ & -0.78 & -2.30 & 10.87 & P5XP3 & $34.62 * *$ & -4.67 & -6.13 & 6.52 \\
\hline P3XP6 & $34.48 * *$ & -2.90 & -10.34 & 1.74 & P6XP3 & 11.21 & $-19.71 * *$ & $-25.86 * *$ & $-15.87 *$ \\
\hline P3XP7 & $38.41 * *$ & 2.71 & $-13.03 *$ & -1.30 & P7XP3 & 8.54 & $-19.46 * *$ & $-31.80 * *$ & $-22.61 * *$ \\
\hline P3XP8 & $40.25 * *$ & 5.69 & $-14.56^{*}$ & -3.04 & P8XP3 & $24.53 * *$ & -6.16 & $-24.14 * *$ & $-13.91 *$ \\
\hline P3XP9 & $30.97 * *$ & 0.00 & $-22.22 * *$ & -11.74 & P9XP3 & $37.42 * *$ & 4.93 & $-18.39 * *$ & -7.39 \\
\hline P3XP10 & $25.00 * *$ & $-13.36 *$ & -8.05 & 4.35 & P10XP3 & $17.19 *$ & $-18.77 * *$ & $-13.79 *$ & -2.17 \\
\hline P4XP5 & -6.35 & $-12.24 *$ & -1.15 & 12.17 & P5XP4 & $-21.96 * *$ & $-26.87 * *$ & $-17.62 * *$ & -6.52 \\
\hline P4XP6 & 10.65 & 0.68 & $13.41 *$ & $28.70 * *$ & P6XP4 & 2.24 & -6.97 & 4.79 & $18.91 * *$ \\
\hline P4XP7 & $13.40 *$ & -0.68 & $11.88 *$ & $26.96 * *$ & P7XP4 & 1.75 & $-10.88 *$ & 0.38 & $13.91 *$ \\
\hline P4XP8 & 6.53 & -8.50 & 3.07 & $16.96 * *$ & P8XP4 & -8.32 & $-21.26 * *$ & $-11.30 *$ & 0.65 \\
\hline P4XP9 & $13.88 *$ & -3.74 & 8.43 & $23.04 * *$ & P9XP4 & $-22.74 * *$ & $-34.69 * *$ & $-26.44 * *$ & $-16.52 *$ \\
\hline P4XP10 & 9.28 & 6.12 & $19.54 * *$ & $35.65 * *$ & P10XP4 & -0.53 & -3.40 & 8.81 & $23.48 * *$ \\
\hline P5XP6 & 3.21 & 0.00 & -1.53 & 11.74 & P6XP5 & -7.63 & -10.51 & $-11.88 *$ & 0.00 \\
\hline P5XP7 & 10.88 & 3.11 & 1.53 & $15.22 *$ & P7XP5 & $13.81 *$ & 5.84 & 4.21 & $18.26 * *$ \\
\hline P5XP8 & 7.26 & -2.33 & -3.83 & 9.13 & P8XP5 & 6.41 & -3.11 & -4.60 & 8.26 \\
\hline P5XP9 & 10.00 & -1.56 & -3.07 & 10.00 & P9XP5 & -8.26 & $-17.90 * *$ & $-19.16^{* *}$ & -8.26 \\
\hline P5XP10 & 1.87 & -1.81 & 4.21 & $18.26 * *$ & P10XP5 & $-14.23 *$ & $-17.33 * *$ & $-12.26^{*}$ & -0.43 \\
\hline P6XP7 & 3.03 & -1.24 & -8.81 & 3.48 & P7XP6 & 12.55 & 7.88 & -0.38 & $13.04 *$ \\
\hline P6XP8 & $-17.26 * *$ & $-22.41 * *$ & $-28.35^{* *}$ & $-18.70 * *$ & P8XP6 & -6.64 & $-12.45 *$ & $-19.16^{* *}$ & -8.26 \\
\hline P6XP9 & 4.05 & -4.15 & $-11.49 *$ & 0.43 & P9XP6 & 11.49 & 2.70 & -5.17 & 7.61 \\
\hline P6XP10 & $18.92 * *$ & $11.19 *$ & $18.01 * *$ & $33.91 * *$ & P10XP6 & 8.88 & 1.81 & 8.05 & $22.61 * *$ \\
\hline P7XP8 & $16.20 *$ & $13.57 *$ & -3.83 & 9.13 & P8XP7 & 0.46 & -1.81 & $-16.86^{* *}$ & -5.65 \\
\hline P7XP9 & 5.19 & 0.90 & $-14.56 *$ & -3.04 & P9XP7 & $21.23 * *$ & $16.29 *$ & -1.53 & 11.74 \\
\hline P7XP10 & 0.00 & -10.11 & -4.60 & 8.26 & P10XP7 & 2.21 & -8.12 & -2.49 & 10.65 \\
\hline P8XP9 & $22.07 * *$ & $12.45^{*}$ & 3.83 & $17.83 * *$ & P9XP8 & $22.07 * *$ & $12.45^{*}$ & 3.83 & $17.83 * *$ \\
\hline P8XP10 & $15.44 * *$ & 7.94 & $14.56^{*}$ & $30.00 * *$ & P10XP8 & $29.73 * *$ & $21.30 * *$ & $28.74 * *$ & $46.09 * *$ \\
\hline P9XP10 & $-23.75 * *$ & $-33.94 * *$ & $-29.89 * *$ & $-20.43 * *$ & P10XP9 & -11.25 & $-23.10 * *$ & $-18.39 * *$ & -7.39 \\
\hline
\end{tabular}

\subsection{Total yield per plant (g)}

Results showed in table (8) exhibited that the highest significant positive heterosis was detected in the straight hybrid P8 X P9 (66.69\%)(59.37\%) over mid and better parents. While, the significant positive lowest values were in the hybrids P4 X P8 (11.41\%) and P2 X P8 (10.48\%) over mid and better parents, respectively. The only high significant negative value was in the hybrid P9 X P10 (-19.16\%) over mid-parent and most of the rest hybrids showed almost high significant positive effects. In addition, four hybrids over better parent showed different levels of negative heterosis and some hybrids showed significant or high significant positive heterosis. Regard to check 1 and 2, six and seventeen hybrids showed positive effects, the highest significant positive heterosis was appeared in the hybrid P1 X P8 (28.16\%)(46.09\%) over check 1 and 2, respectively. While, the significant positive lowest values were in the hybrids P4 X P10 (10.06\%) and P1 X P6 (10.53\%) over check 1 and 2, respectively. On the opposite, some hybrids showed significant or high significant negative heterosis over check 1(Aziad) and only three hybrids showed high significant negative effects over check 2 (New Eskandarani). In respect to reciprocal crosses, the highest significant positive value was in the hybrid P3 X P1 $(69.11 \%)$ and P10 X P8 $(70.27 \%)$ over mid and better parents. While, the significant positive lowest values were detected in the hybrids P4 X P1 (12.28\%) and P7 X P5 (12.68\%) over mid and better parents. In addition, two and four hybrids showed significant or high significant negative heterosis over mid and better 
parents, respectively. Moreover, some hybrids indicated significant or high significant positive heterosis over mid and better parents. For check varieties, the highest significant positive values was in the hybrid P10 X P8 $(49.51 \%)(70.44 \%)$ over check 1 and 2 , respectively. In addition, three more hybrids showed high significant positive effects over check 1 and the rest of hybrids reported significant or high significant negative values. On the other hand, some hybrids indicated significant or high significant positive or negative values over check 2 . These data were presented by Marxmathi et al., (2018a), Restrepo (2018), Elsharkawy et al. (2018), El shoura et al. (2018), Hikal and Abdein (2018), Gad Allah (2019).

Table 8. Estimation of heterosis percentage of F1 hybrids and their reciprocals relative to mid and better parents and two commercial checks for yield traits - Total yield/plant $(\mathrm{g})$

\begin{tabular}{|c|c|c|c|c|c|c|c|c|c|}
\hline $\mathrm{F} 1$ & H. Mp & H. Bp & H. CV 1 & H. CV 2 & F1r & H. Mp & H. Bp & H. CV 1 & H. CV 2 \\
\hline P1XP2 & $33.06 * *$ & $32.58 * *$ & 3.78 & $18.30 * *$ & P2XP1 & $49.38 * *$ & $48.84 * *$ & $16.50 * *$ & $32.81 * *$ \\
\hline P1XP3 & $56.92 * *$ & $25.02 * *$ & -2.14 & $11.55^{*}$ & P3XP1 & $69.11 * *$ & $34.72 * *$ & 5.46 & $20.22 * *$ \\
\hline P1XP4 & $28.05 * *$ & $15.91 * *$ & $11.95 * *$ & $27.61 * *$ & P4XP1 & $12.28 *$ & 1.64 & -1.83 & $11.90 *$ \\
\hline P1XP5 & $13.69 *$ & 8.69 & -6.71 & 6.35 & P5XP1 & 6.59 & 1.90 & $-12.53 * *$ & -0.29 \\
\hline P1XP6 & $25.27 * *$ & $23.87 * *$ & -3.04 & $10.53 *$ & P6XP1 & $48.25 * *$ & $46.60 * *$ & $14.75^{* *}$ & $30.81 * *$ \\
\hline P1XP7 & $37.90 * *$ & $31.85 * *$ & 3.21 & $17.65^{* *}$ & P7XP1 & $31.79 * *$ & $26.00 * *$ & -1.37 & $12.43 *$ \\
\hline P1XP8 & $55.28 * *$ & $47.67 * *$ & $28.16 * *$ & $46.09 * *$ & P8XP1 & $31.76 * *$ & $25.30 * *$ & 8.75 & $23.97 * *$ \\
\hline P1XP9 & $26.63 * *$ & $19.79 * *$ & -6.23 & 6.89 & P9XP1 & $15.03 *$ & 8.81 & $-14.83 * *$ & -2.91 \\
\hline P1XP10 & $25.23 * *$ & $18.43 * *$ & 4.00 & $18.55^{* *}$ & P10XP1 & -5.21 & $-10.35^{*}$ & $-21.28 * *$ & $-10.26^{*}$ \\
\hline P2XP3 & 2.99 & $-17.73 * *$ & $-36.07 * *$ & $-27.12 * *$ & P3XP2 & $44.53 * *$ & $15.46 * *$ & $-10.28 *$ & 2.27 \\
\hline P2XP4 & 8.30 & -2.28 & -5.63 & 7.58 & P4XP2 & 6.38 & -4.01 & -7.3 & 5.68 \\
\hline P2XP5 & 7.77 & 2.66 & $-11.88 * *$ & 0.46 & P5XP2 & 8.16 & 3.04 & $-11.56^{*}$ & 0.82 \\
\hline P2XP6 & 7.10 & 6.29 & $-17.40 * *$ & -5.84 & P6XP2 & $32.15 * *$ & $31.15 * *$ & 1.91 & $16.17 * *$ \\
\hline P2XP7 & $25.96 * *$ & $20.86 * *$ & -6.09 & 7.06 & P7XP2 & $21.28 * *$ & $16.36^{* *}$ & $-9.58 *$ & 3.07 \\
\hline P2XP8 & $16.58 * *$ & $10.48 *$ & -4.12 & 9.3 & P8XP2 & $31.19 * *$ & $24.32 * *$ & 7.90 & $23.00 * *$ \\
\hline P2XP9 & $16.16 * *$ & 10.26 & $-14.32 * *$ & -2.33 & P9XP2 & 9.43 & 3.87 & $-19.29 * *$ & -7.99 \\
\hline P2XP10 & $19.63 * *$ & $12.75^{*}$ & -1.00 & $12.86 *$ & P10XP2 & 5.27 & -0.79 & $-12.88 * *$ & -0.69 \\
\hline P3XP4 & $18.66 * *$ & $-12.14 * *$ & $-15.15^{* *}$ & -3.27 & P4XP3 & 5.82 & $-21.65 * *$ & $-24.33 * *$ & $-13.74 * *$ \\
\hline P3XP5 & $28.95 * *$ & -0.64 & $-14.71 * *$ & -2.78 & P5XP3 & $42.85 * *$ & 10.07 & -5.52 & 7.71 \\
\hline P3XР6 & $58.36^{* *}$ & $27.23 * *$ & -2.63 & $11.00 *$ & P6XP3 & $32.78 * *$ & 6.68 & $-18.36^{* *}$ & -6.93 \\
\hline P3XP7 & $33.04 * *$ & 9.79 & $-21.61 * *$ & $-10.63^{*}$ & P7XP3 & 9.20 & -9.89 & $-35.66 * *$ & $-26.65 * *$ \\
\hline P3XP8 & $44.22 * *$ & $10.70 *$ & -3.92 & 9.52 & P8XP3 & $28.08 * *$ & -1.69 & $-14.67 * *$ & -2.73 \\
\hline P3XP9 & $28.17 * *$ & 6.72 & $-25.50 * *$ & $-15.07 * *$ & P9XP3 & $46.12 * *$ & $21.67 * *$ & $-15.06 * *$ & -3.17 \\
\hline P3XP10 & $41.71 * *$ & 8.33 & -4.88 & 8.44 & P10XP3 & $36.41 * *$ & 4.28 & -8.43 & 4.38 \\
\hline P4XP5 & -4.63 & $-9.94 *$ & $-13.02 * *$ & -0.85 & P5XP4 & $15.11 * *$ & 8.71 & 4.99 & $19.68 * *$ \\
\hline P4XP6 & $21.55^{* *}$ & 8.94 & 5.21 & $19.93 * *$ & P6XP4 & $16.29 * *$ & 4.22 & 0.65 & $14.74 * *$ \\
\hline P4XP7 & $15.28 * *$ & 0.25 & -3.18 & $10.37 *$ & P7XP4 & 9.28 & -4.96 & -8.21 & 4.63 \\
\hline P4XP8 & $11.41^{*}$ & 5.76 & 2.14 & $16.44 * *$ & P8XP4 & $13.30 * *$ & 7.56 & 3.88 & $18.42 * *$ \\
\hline P4XP9 & $15.53 * *$ & -0.48 & -3.88 & 9.57 & P9XP4 & $-45.25 * *$ & $-52.84 * *$ & $-54.45 * *$ & $-48.08 * *$ \\
\hline P4XP10 & $19.38 * *$ & $13.97 * *$ & $10.06 *$ & $25.47 * *$ & P10XP4 & $9.89 *$ & 4.91 & 1.32 & $15.50 * *$ \\
\hline P5XP6 & $15.66^{* *}$ & 9.39 & -6.11 & 7.03 & P6XP5 & 8.19 & 2.33 & $-12.17 * *$ & 0.13 \\
\hline P5XP7 & 8.58 & -0.55 & $-14.63 * *$ & -2.69 & P7XP5 & $23.02 * *$ & $12.68 *$ & -3.28 & $10.26^{*}$ \\
\hline P5XP8 & 2.39 & 1.83 & $-11.63 *$ & 0.74 & P8XP5 & $19.94 * *$ & $19.28 * *$ & 3.52 & $18.01 * *$ \\
\hline P5XP9 & $15.08 * *$ & 4.34 & $-10.44^{*}$ & 2.09 & P9XP5 & $-14.72 *$ & $-22.68 * *$ & $-33.63 * *$ & $-24.34 * *$ \\
\hline P5XP10 & 7.14 & 5.93 & -6.98 & 6.04 & P10XP5 & 3.21 & 2.05 & $-10.39 *$ & 2.16 \\
\hline P6XP7 & $17.01 * *$ & $13.09 *$ & $-13.45 * *$ & -1.34 & P7XP6 & $32.20 * *$ & $27.77 * *$ & -2.22 & $11.47 *$ \\
\hline P6XP8 & 1.23 & -4.75 & $-17.33 * *$ & -5.76 & P8XP6 & 7.09 & 0.76 & $-12.55 * *$ & -0.31 \\
\hline P6XP9 & $19.13 * *$ & $13.90 *$ & $-12.83 * *$ & -0.63 & P9XP6 & $34.49 * *$ & $28.58 * *$ & -1.59 & $12.18 *$ \\
\hline P6XP10 & $34.68 * *$ & $26.02 * *$ & $10.66^{*}$ & $26.15 * *$ & P10XP6 & $31.07 * *$ & $22.65 * *$ & 7.70 & $22.77 * *$ \\
\hline P7XP8 & $26.62 * *$ & $15.40 * *$ & 0.15 & $14.17 * *$ & P8XP7 & $17.17 * *$ & 6.79 & -7.32 & 5.65 \\
\hline P7XP9 & $16.42 *$ & $15.12 *$ & $-17.80 * *$ & -6.29 & P9XP7 & $33.98 * *$ & $32.49 * *$ & -5.40 & 7.84 \\
\hline P7XP10 & $19.42 * *$ & 8.26 & -4.93 & 8.37 & P10XP7 & $12.95 *$ & 2.40 & $-10.08^{*}$ & 2.50 \\
\hline P8XP9 & $66.69 * *$ & $59.37 * *$ & $21.97 * *$ & $39.04 * *$ & P9XP8 & $66.58 * *$ & $59.27 * *$ & $21.89 * *$ & $38.95 * *$ \\
\hline P8XP10 & $50.37 * *$ & $40.71 * *$ & $23.56 * *$ & $40.85 * *$ & P10XP8 & $81.95 * *$ & $70.27 * *$ & $49.51 * *$ & $70.44 * *$ \\
\hline P9XP10 & $-19.16 * *$ & $-27.44 * *$ & $-36.29 * *$ & $-27.37 * *$ & P10XP9 & $14.12 *$ & 2.42 & $-10.06^{*}$ & 2.53 \\
\hline
\end{tabular}


3- Phenotypic correlation

Data illustrated in Table (9) showing the estimation of phenotypic correlation coefficient between the sixteen studied traits.

Table 9. Estimation of phenotypic correlation among studied traits.

\begin{tabular}{|c|c|c|c|c|c|c|}
\hline & D.F.F.F & Sex ratio & F.W.g & T.S.S. \% & N.F.P. & T.Y.P.g \\
\hline D.F.F.F & & $0.48 * *$ & $0.18 * *$ & 0.03 & $-0.49 * *$ & $-0.37 * *$ \\
\hline Sex ratio & & & $0.27 * *$ & 0.00 & $-0.67 * *$ & $-0.50 * *$ \\
\hline F.W. g & & & & -0.01 & $-0.16 * *$ & $0.24 * *$ \\
\hline T.S.S. \% & & & & & -0.05 & -0.04 \\
\hline N.F.P. & & & & & & $0.74 * *$ \\
\hline
\end{tabular}

*Correlation is significant at the 0.05 level (2-taild).

**Correlation is significant at the 0.01 level (2-taild).

For number of days to first female flower, results showed that high significant positive correlation with sex ratio and fruit weight. On the other side, high significant negative correlation between the studied trait with number of fruits per plant and total yield per plant.

Regarding to sex ratio, data showed that high significant positive correlation with fruit weight. While, high significant negative correlation was found with number of fruits per plant and total yield per plant.

Relative to fruit weight, data revealed that high significant negative and positive correlation with number of fruits per plant and total yield per plant, respectively.

For total soluble solids, the correlation with other traits was found insignificant.

Concerning to number of fruits per plant, results revealed that high significant positive correlation was found with total yield per plant. These data were in agreement with Panigrahi et al., (2018), Raut et al., (2018) and Gad Allah (2019).

\section{References}

Abdein, M. A.; H. M. F. Hassan and H. M. Dalia. 2017. General performance, combining ability and heritability of yield and yield component traits in Pumpkin (Cucurbita mochata Duch. Ex. Poir.) at different conditions. KMITL Sci. Tech. J., 17(1):121-129.

Chaudhari, D.J. ; R.R. Acharya ; J.N. Patel ; S.B. Gohil and K.C. Bhalala. 2017. Variability, correlation and path analysis in pumpkin (Cucurbita mochata Duch. Ex. Poir.). J. Phamacognosy and Phaytochemistry, 6(6): 142145.

Damarany, A.M., H.M. Aboul-Nasr and M.M.A. Abdalla. 1995. Yield and yield components of some Cucurbita spp. Cultivars and hybrids under Assiut conditions: I. summer squash (Cucurbita pepo L.). Assiut J. Agric. Sci. 26:51-57.

Elsharkawy, S. E. M. ; L.A.A. Badr ; A. S. Shams and E. M. Khalil. 2018. Heterosis and combining ability studies for fruit yield and quality characters in squash (Cucurbita pepo L.).Annals of Agric. Sci., Moshtohor Vol. 56(3): 731-740.

El-shoura, A.M. and M. Y. Abed. 2018. Heterosis and combining ability for development of squash hybrids (Cucurbita pepo L.). J. Plant Production, Mansoura Univ., Vol. 9(12): 1181 - 1187. ElTahawey M.A.F.A., A.M. Kandeel, S.M.S. Youssef and M.M.M. Abd El-Salam. 2015. Heterosis, potence ratio, combining ability and correlation of some economic traits in diallel crosses of pumpkins. Egypt, J. Plant Breeding. 19(2):419-439.

Gomez, K.N. and A.A. Gomez (1984). Statistical Procedures for Agricultural Research. John. Wiley and Sons. Inc., New York, $2^{\text {nd }}$ ed.

Hassan, A.A. 1988. Cucurbits. Arabic House for publishing and distribution, Cairo, Egypt (in Arabic). PP. 413.

Hatem, M.K.; A.K. Hatem and M.A.Abd Alla. 2013. Studies on the inheritance and types of gene action for some summer squash characters. J. Agric. Res., Kafrb El-Sheikh Univ., 39 (3): 423444.

Hikal, Dalia M. and M. A. Abdein. 2018. Nutritional and genetically studies on some squash varieties. Researcher, 10(12):112-118).

Hussien , A. H. 2015. Nature of gene action and heterosis performance for yield and yield components in summer squash (Cucurbita pepo L. ) . J. Plant Production, Mansoura Univ., 6(1): 29 -40 .

Hussien, A. H. and A. A. Hamed. 2015. Diallel analysis for studying heterosis and combining ability of some economical yield traits in pumpkin. J. Plant Production, Mansoura Univ., 6 (3):261270.

Jahan, T. A. ; A. K. Islam; M. G. Rasul; M. A. Main and M. M. Haque. 2012. Heterosis of qualitative and quantative characters in sweet gourd (Cucurbita mochata Duch.ex Poir). Bangaladesh, 12(3):6186-6199.

Marie, A.K.; M.Y. Moulla and M.G. Boras. 2012. Heterosis study of some quantity characters of squash (Cucurbita pepo, L.). Damascus Univ. J. Agric. Sci., 28 (1):339-354. 
Marxmathi,P. ; V. Krishnamoorthy and P. Thnkaraja. 2018a. Studies on heterosis in pumpkin (Cucurbita mochata Duch. Ex. Poir). Int. J. Curr. Microbiol. App. Sci., 7(3): 3025-3032.

Marxmathi, P. ; V. Krishnamoorthy and P. Thnkaraja. 2018b. Combining ability studies in pumpkin (Cucurbita mochata Duch. ex. Poir). Int. J. Curr. Microbiol. App. Sci., 7(3): 3033-3039.

Maynard, D. N., Ed., 2001. Watermelons, Characteristics, Production and Marketing, Alexandria, VA: ASHS Press.

Metwally, E. I. (1985). Inheritance studies on squash crop. Ph.D. Thesis, Fac. of Agric, Tanta Univ., Egypt.

Mohamed, M. I. A. 2016a. Squash hybrid production and genetic studies on some important characters. M.Sc. Thesis, Fac. Agric., Cairo Univ., P112.

Mohamed, M. A. M. A. 2016b. The performance of parental lines and their hybrids resulted from diallel crosses mating design in squash (Cucurbita pepo L.). Ph.D. Thesis, Fac. Agric., Mansoura Univ., P 216.

Obiadallah-Ali, H. A. 2006. Heterosis and nature of gene action for earliness and yield components in summer squash (Cucurbita pepo L.). Assuit J. Agric. Sci., 37(1):123-135.

Gad Alla, O.A.M. 2019. Studies on newly production cucumber hybrids (Cucumis sativus L.) in Egypt. Ph.D., Fac. Agric., Ain Shams Univ. P. 90.

Othman, I. A. H. 2016. Genetic Analysis of some important traits in squash (Cucurbita pepo L.). M.Sc. Thesis, Fac. Agric., Mansoura Univ., P. 89.

Panigrahi J. ; DS Duhan ; VPS Panghal ; SK Tehlan and AC Yadav. 2018. Correlation coefficient analysis between yield defining traits of cultivated genotypes of bottle gourd (Lagenaria siceraria (Mol.) Stdl.). J. of Pharmacognosy and Phytochemistry, 7(2): 1378-1380.

Paris, H. S. (1996). Summer Squash: History, diversity, and distribution. Hort. Technology 6: 613.

Raut R.L. ; S.P. Mishra and Sharad Bisen. 2018. Path analysis and correlation study of yield and its measure contributing traits in bottle gourd ( Lagenaria siceraria (Mol.) Standl). Int. Curr. Microbio. App. Sci. 7(12): 1256 - 1263.

Restrepo J. ; F. Vallejo and E. Restrepo. 2018. Yield heterosis and average fruit weight as a function of inbreeding in Cucurbita mochata Duch. Ex Poir. Agronomia Colombiana, 36(1): 512.

Steel, R.G.D. and Torrie, J.H. (1980). Principles and procedures of statistics. A piometrical approach. $2^{\text {nd }}$ edition, Mc Graw-Hill Book Co., New York, 688-692.

Tamil, N.A.; P. Jansirani; L. Pugalendhi and A. Nirmalakumari. 2012. Per se performance of genotypes and correlation analysis in pumpkin (Cucurbita mochata Duch. Ex Poir). Electronic J. Plant Breed. 3(4): 987-994.

Tamiselvi, N. A.; P. Jansirani and L. Pugalendhi. 2015. Estimation of heterosis and combining ability for earliness and yield characters in pumpkin (Cucurbita mochata Duch. Ex. Poir). African J. Agric. Res., 10(16): 1904-1912.

Waly, E.A. and A. Nassar. 1978. Genetical investigation in squash (Cucurbita pepo L.): Studies on leaf, flower and fruit characters. Assiut J. Agric. Sci. 9:19-37.

Whitaker, T. W. and R. W. Robinson. 1986. Breeding vegetable crops AVI publishing Co. ISBN 0-87055-499-9. P. 209-210. 


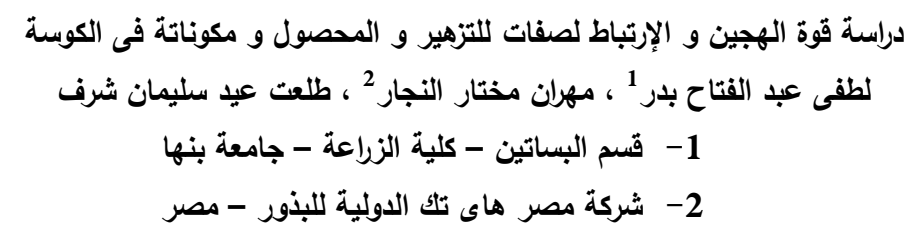

الهدف الأساسى من هذه الدراسة هو دراسة توريث بعض الصفات الإقتصادية فى بعض التراكيب الوراثية فى الكوسة والهجن العادية والهجن

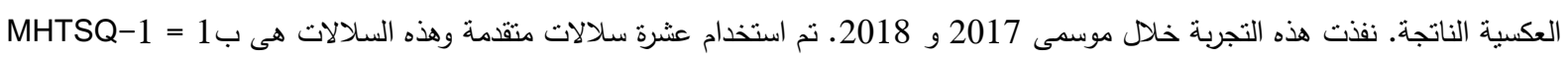

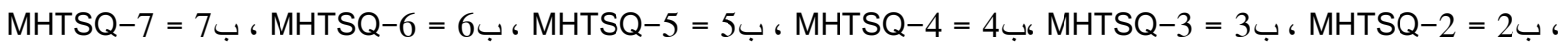

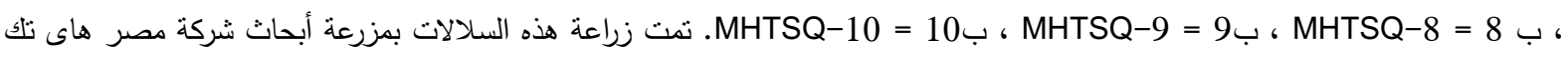

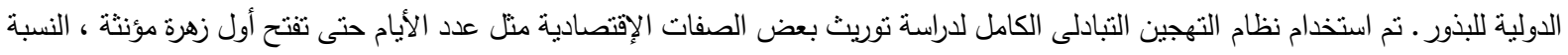

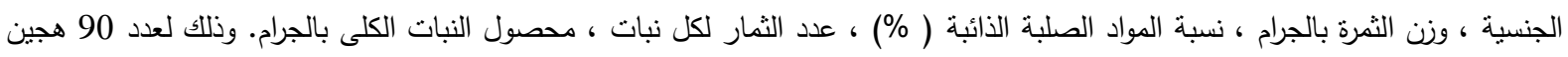

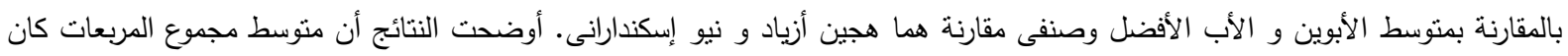

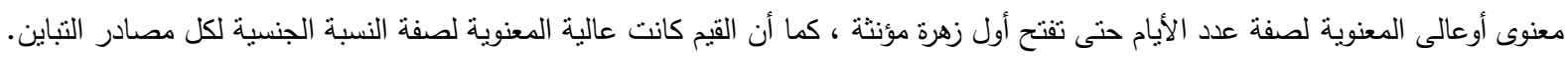

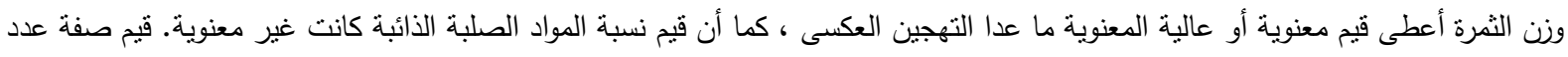

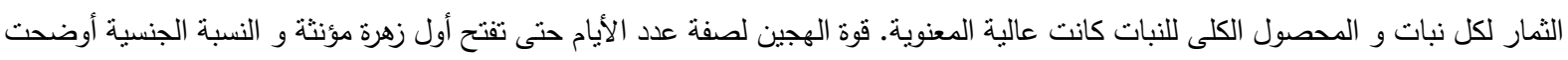

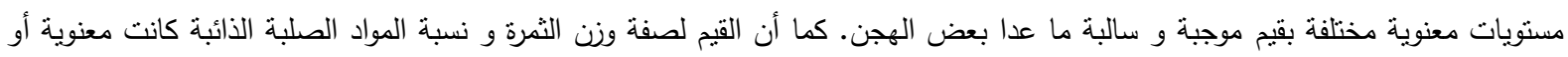

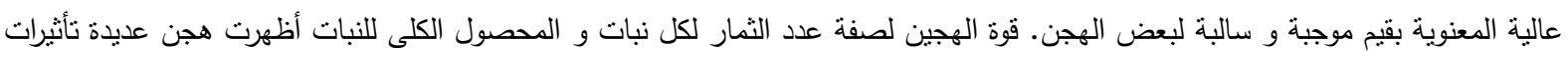

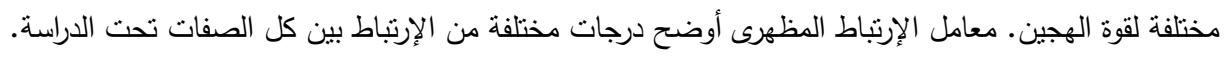

